\title{
EKSPLORASI SPATIAL DAN IDENTIFIKASI CENDAWAN ENDOFIT PADA TANAMAN KAKAO (Theobroma cacao L.) DI BALI
}

\author{
(SPATIAL EXPLORATION AND PLANT IDENTIFICATION ENDOPHYTIC FUNGI COCOA \\ (Theobroma cacao L.) IN BALI \\ *Lilis Riana Tambunan, Meitini Proborini, Putu Adriani Astiti \\ PS. Biologi FMIPA, Universitas Udayana, Bukit Jimbaran Bali \\ *Email: Riana.lilis212@gmail.com
}

\section{INTISARI}

Pertumbuhan tanaman kakao (Theobroma cacao L.) dipengaruhi oleh faktor lingkungan, hara, tanah dan mikroorganisme. Salah satu mikroorganisme yang dapat mempengaruhi pertumbuhan tanaman kakao adalah cendawan endofit. Cendawan endofit adalah cendawan yang hidup pada jaringan tumbuhan seperti biji, daun, bunga, ranting, batang dan akar yang bersifat mutualistik dan diketahui dapat memacu pertumbuhan tanaman, mampu menghasilkan antibiotika dan zat pengatur tumbuh (hormon). Penelitian ini bertujuan untuk mengetahui keragaman dan identifikasi jenis cendawan endofit pada kakao.yang ditemukan di dua lokasi berbeda di Bali yaitu di Desa Buahan Kaja Kecamatan Payangan, Gianyar dan Desa Tua kecamatan Marga, Tabanan. Penelitian menggunakan metode eksplorasi, isolasi, identifikasi dan analisa keragaman jenis dilakukan di Laboratorium Taksonomi Tumbuhan (Mikologi), Jurusan Biologi, Fakultas MIPA Universitas Udayana. Penelitian di laboratorium dilakukan dengan cara mengisolasi bagian akar, daun, batang tanaman dan kandungan tanah (Rizosfer) kakao dan ditumbuhkan pada medium PDA dan diinkubasi pada suhu ruang $25^{\circ} \mathrm{C}$. Terdapat cendawan spatial pada tanaman kakao dan tidak ditemukan perbedaan jenis cendawan (endofit) spatial , perbedaan hanya terdapat pada sampel ditemukan atau tidak diytemukannya pada daun, batang akar, atau rizosfer tanaman. Sebanyak enam isolat cendawan endofit teridentifikasiyaitu Aspergillus flavus, Rhizopus stolonifer, Cladosporium macrocarpum, Trichoderma viride, isolat sp. 1 dan sp. isolat 2.

Kata Kunci : kakao, cendawan endofit, dataran tinggi, dataran rendah

\section{ABSTRACT}

Cocoa plant (Theobroma cacao L.) can grow well in the highlands and lowlands, a plantation and industrial plant which is known as one of the export commodities, as raw material for the food and pharmaceutical industries which can contribute to an increase in foreign exchange endophytic fungus is a fungus living on a live network of plants such as seeds, leaves, flowers, twigs, stems and roots. Truffles are generally mutualistic endophyte and is known to stimulate the growth of plants, capable of producing antibiotics and plant growth regulators (hormones). This study aims to determine the diversity and identify endophytic fungi on Kakao.yang found in two different locations in Bali, in the village of Kaja Buahan District of Payangan, Gianyar and the Village of Tua, Marga, Tabanan regency subdistricts. Research carried out in the field with the exploration methods, isolation, identification and diversity analysis conducted at the Laboratory of Plant Taxonomy (Mycology), Department of Biology, Faculty of Mathematics, University of Udayana. Laboratory research conducted by isolating the roots, leaves, plant stems and content of the soil (rhizosphere) cocoa. Once isolated, grown on PDA medium subsequently incubated at room temperature $25^{\circ} \mathrm{C}$. Isolates that grow back isolated and purified on a PDA medium for further identified to the genera or species level. A total of six isolates of endophytic fungi identified in the rhizosphere and cocoa plant that is where four of these isolates were identified to species, two isolates were not identified until genus. Fungi were identified namely Aspergillus flavus, Rhizopus stolonifer, Cladosporium sphaeropermum, Trichoderma viride, isolates 1 and 2 isolates.

Keywords: cocoa, endophytic fungi, highlands and lowlands

\section{PENDAHULUAN}

Kakao (Theobroma cacao L.) merupakan tanaman perkebunan industri dan dikenal sebagai salah satu komoditas ekspor yang dapat memberikan kontribusi untuk peningkatan devisa negara dan sangat dibutuhkan sebagai bahan baku makanan dan farmasi (Firdausil dkk., 2008). Iklim dan kontur tanah di Indonesia sangat sesuai untuk pengembangan tanaman kakao. Berdasarkan data yang dipublikasikan oleh Dinas Perkebunan Kehutanan Tanaman Pangan dan Hortikultura (2011), dengan luas produktivitas tanaman kakao terus membaik sehingga lahan yang digunakan terus meningkat.

Pertumbuhan tanaman kakao (Theobroma cacao L.) dipengaruhi oleh faktor lingkungan, hara, tanah dan mikroorganisme. Salah satu mikroorganisme yang dapat mempengaruhi pertumbuhan tanaman kakao adalah cendawan endofit. Cendawan endofit dapat hidup di dalam jaringan tumbuhan, seperti daun, bunga, ranting ataupun akar tumbuhan dan mampu hidup dengan membentuk koloni dalam jaringan tanaman tanpa membahayakan inangnya. Menurut Sriwati (2012), cendawan endofit diketahui dapat memacu perkecambahan, meningkatkan ketahanan tanaman dan dapat memproduksi senyawa metabolit sekunder sesuai dengan tanaman inang. peningkatkan pertumbuhan tanaman inang yaitu melalui mekanisme peningkatan penyerapan nutrisi atau dengan produksi hormon pengatur tumbuh (Rosmana dkk., 2006).

Desa Buahan Kaja merupakan salah satu desa di kecamatan Payangan, Gianyar. Desa ini memiliki dataran tinggi dengan ketinggian 600 sampai dengan 700 mdpl dan beriklim tropis, dimana sepanjang tahun mendapatkan curah hujan yang cukup tinggi. Sedangkan Desa Tua Kecamatan Marga, Tabanan memiliki curah hujan yang cukup rendah dengan ketinggian 300 sampai 500 mdpl. Pertumbuhan tanaman kakao dapat ditemukan di dataran tinggi dan dataran rendah pada kedua desa tersebut. Namun, belum banyak diketahui penelitian tentang cendawan endofit pada tanaman kakao di daerah dataran tinggi dan dataran rendah. Dengan alasan tersebut, maka penelitian dilakukan untuk mengetahui tentang cendawan endofit pada tanaman kakao yang ditemukan dikawasan yang berbeda dan untuk mengetahui perbedaan jenis-jenis cendawan yang terdapat pada tanaman kakao yang diperoleh dikedua kawasan tersebut (Kariada, 2012). 


\section{MATERI DAN METODE}

\section{Pembuatan media}

Alat-alat yang digunakan seperti cawan petri, gelas becker dan erlenmeyer dibersihkan terlebih dahulu. Pembuatan media PDA (Potato Dextrose Agar) 1 liter dilakukan dengan mengupas kentang dan dipotong menjadi empat bagian, direbus dalam $800 \mathrm{~mL}$ aquades sampai mendidih, air rebusan kentang diambil ekstraknya. Kemudian air ekstrak kentang dicampur dengan agar sebanyak 15 gram dan dextrose sebanyak 10 gdilarutkan dalam $200 \mathrm{~mL}$ aquades (Proborini, 2002)

\section{Metode Penelitian}

\section{Isolasi cendawan}

Sampel daun, batang dan akar disterilkan menggunakan byclean $1 \%$, dicuci dengan aquades 5 menit dan dikering anginkan menggunakan tissue steril, sampel ditanam di atas media PDA pada cawan petri dan selanjutnya diinkubasi selama 2-3 hari. Sampel rizosfer ditimbang sebanyak 10 gr,dimasukkan ke dalam botol berisi air steril $90 \mathrm{~mL}$ dan dikocok hingga homogen. Sebanyak 1 mLdiambil dan dimasukkan ke dalam tabung reaksi berisi $9 \mathrm{~mL}$ air steril, lalu dikocok dan diulangi hingga pengenceran $10^{-4}$. Selanjutnya diambil $1 \mathrm{~mL}$ dari setiap tabung reaksi untuk dimasukkan ke dalam cawan, dituangkan media PDA ke dalamnya. Sampel kemudian diinkubasi selama 2 - 3 hari lalu diamati dan diidentifikasi.

\section{Reisolasi dan pembuatan biakan murni}

Biakan murni dibuat dengan cara mengambil miselium atau spora cendawan pada sampel yang telah diisolasi menggunakan jarum ose dan dibiakkan pada cawan petri yang telah diisi media PDA (Proborini, 2002).

\section{Identifikasi Cendawan}

Pengamatan makroskopis diamati warna koloni cendawan, warna sebalik koloni dan permukaaan koloninya. Pengamatan mikroskopis dilakukan dengan cara hifa atau spora diambil dengan menggunakan jarum ose, diletakkan pada obyek glass yang diberi laktofenol blue dan ditutup dengan cover glass (Proborini, 2002).

\section{HASIL}

\section{Total Koloni Cendawan}

Hasil perhitungan total koloni cendawan pada sampel rizosfer tanaman kakao diperoleh dari hasil pengenceran $10^{-4}$.

Total koloni cendawan tertinggi terdapat pada lokasi dataran rendah (Desa Tua, Tabanan) sebesar 27,47× $10^{4}$ $\mathrm{CFU} / \mathrm{g}$ sementara total cendawan terendah terdapat pada lokasi dataran tinggi (Desa Buahan, Payangan) sebesar 5,09 $\times 10^{4}$. Adanya perbedaan jumlah koloni cendawan menunjukkan bahwa pada lokasi dataran rendah (Desa Tua, Tabanan), jumlah koloni cendawan lebih padat dibandingkan lokasi dataran tinggi (Desa Buahan, Payangan). Salah satu yang mempengaruhi yaitu suhu dimana pada saat pengambilan sampel di Desa Buahan suhu mencapai $27^{\circ} \mathrm{C}$ dan tanah yang lembab dan berair sementara di Desa Tua suhu mencapai $26^{\circ} \mathrm{C}$ dengan kondisi tanah yang tidak terlalu berair (Kariada, 2012).

\section{Identifikasi Cendawan}

Hasil identifikasi cendawan yang diperoleh pada kedua lokasi sebanyak empat spesies dan dua isolat yaitu Aspergillus flavus, Rhizopus stolonifer, Cladosporium macrocarpum, Trichoderma viride, isolat sp. 1 dan isolat sp.2.

Tinggi rendahnya total koloni cendawan yang diperoleh pada lokasi Desa Buahan dan Desa Tua karena tidak meratanya penyebaran spora cendawan pada saat pengambilan sampel rizosfer dimasing - masing titik tersebut. Hamdani (2009) mengemukakan bahwa keanekaragaman cendawan pada rizosfer pertanaman kakao dipengaruhi oleh jenis tanaman pelindung dan ketinggian tempat, serta teknik budidaya.

Berdasarkan hasil penelitian, jenis cendawan sebanyak enam isolat dengan ciri makroskopis dan mikroskopis sebagai berikut.

\section{Aspergillus flavus}

Makroskopis memiliki diameter $3 \mathrm{~cm}-5 \mathrm{~cm}$, koloni hijau kekuningan, sebalik koloni hijau kuning keabuan, membentuk garis-garis radier. Secara mikroskopis konidia berbentuk bulat, berdiameter $3,6 \mu \mathrm{m}$, konidiofor kasar, vesikula berbentuk bulat hingga semibulat, fialid terbentuk langsung pada vesikula atau pada metula (Gandjar dkk., 1999).

Tabel 1.Total populasi cendawan di dataran tinggi (Desa Buahan, Payangan) dan di dataran rendah (Desa Tua,

Tabanan).

\begin{tabular}{cccc}
\hline \multicolumn{4}{c}{ Lokasi Sampel / Total Koloni Cendawan } \\
\hline $\begin{array}{c}\text { Desa Buahan, } \\
\text { Payangan }\end{array}$ & $\begin{array}{c}\text { Total Koloni } \\
(\text { CFU/g) }\end{array}$ & $\begin{array}{c}\text { Desa Tua, } \\
\text { Tabanan }\end{array}$ & $\begin{array}{c}\text { Total Koloni } \\
\text { (CFU/g) }\end{array}$ \\
\hline $\mathrm{R}_{1}$ & $13,26 \times 10^{4}$ & $\mathrm{~T}_{1}$ & $18,8 \times 10^{4}$ \\
$\mathrm{R}_{2}$ & $5,09 \times 10^{4}$ & $\mathrm{~T}_{2}$ & $27,47 \times 10^{4}$ \\
$\mathrm{R}_{3}$ & $15,72 \times 10^{4}$ & $\mathrm{~T}_{3}$ & $10,64 \times 10^{4}$ \\
$\mathrm{R}_{4}$ & $13,33 \times 10^{4}$ & $\mathrm{~T}_{4}$ & $24,32 \times 10^{4}$ \\
$\mathrm{R}_{5}$ & $10,41 \times 10^{4}$ & $\mathrm{~T}_{5}$ & $23,17 \times 10^{4}$ \\
\hline Keterangan : & & & \\
T1, T2, T3, T4, T5 & $=$ Lokasi Pengambilan Sampel didataran rendah (Desa Tua, Tabanan) \\
R1, R2, R3, R4, R5 & $=$ Lokasi Pengambilan Sampel didataran tinggi (Desa Buahan, Payangan) \\
CFU & $=$ Colony Form Unit (Jumlah Total Cendawan)
\end{tabular}


Tabel 2. Hasil identifikasi cendawan dan tempat ditemukannya di dataran tinggi (Desa Buahan, Payangan)

\begin{tabular}{llllll}
\hline \multirow{2}{*}{ No } & \multirow{2}{*}{ Spesies Cendawan } & \multicolumn{3}{l}{ Bagian Tanaman } \\
\cline { 3 - 6 } & Daun & Batang & Akar & Rizosfer \\
\hline 1 & Aspergillus flavus & $\sqrt{ } \sqrt{ } \sqrt{ }$ & $\sqrt{ } \sqrt{ }$ & $\sqrt{ }$ & $\sqrt{ } \sqrt{ }$ \\
2 & Rhizopus stolonifer & $\sqrt{ } \sqrt{ }$ & $\sqrt{ }$ & $\sqrt{ }$ & $\sqrt{ }$ \\
3 & Cladosporium macrocarpum & $\sqrt{ } \sqrt{ }$ & $\sqrt{ }$ & $\sqrt{ } \sqrt{ }$ & $\sqrt{ }$ \\
4 & Trichoderma viride & $\sqrt{ }$ & $\sqrt{ }$ & $\sqrt{ }$ & - \\
5 & Isolat sp.1 & $\sqrt{ }$ & - & $\sqrt{ }$ & $\sqrt{ } \sqrt{ }$ \\
6 & Isolat sp.2 & - & $\sqrt{ }$ & $\sqrt{ }$ & $\sqrt{ } \sqrt{ }$ \\
\hline
\end{tabular}

Keterangan :

$\sqrt{ } \sqrt{ } \sqrt{ } \sqrt{ }=$ Ditemukan pada lima titik pengambilan sampel tanaman

$\sqrt{ } \sqrt{ } \sqrt{ }=$ Ditemukan pada empat titik pengambilan sampel tanaman

$\sqrt{ } \sqrt{ }=$ Ditemukan pada tiga titik pengambilan sampel tanaman

$\sqrt{ } \sqrt{ }=$ Ditemukan pada dua titik pengambilan sampel tanaman

$\sqrt{ } \quad=$ Ditemukan pada satu titik pengambilan sampel tanaman

Tabel 3. Hasil identifikasi cendawan dan tempat ditemukannya di dataran rendah (Desa Tua, Tabanan)

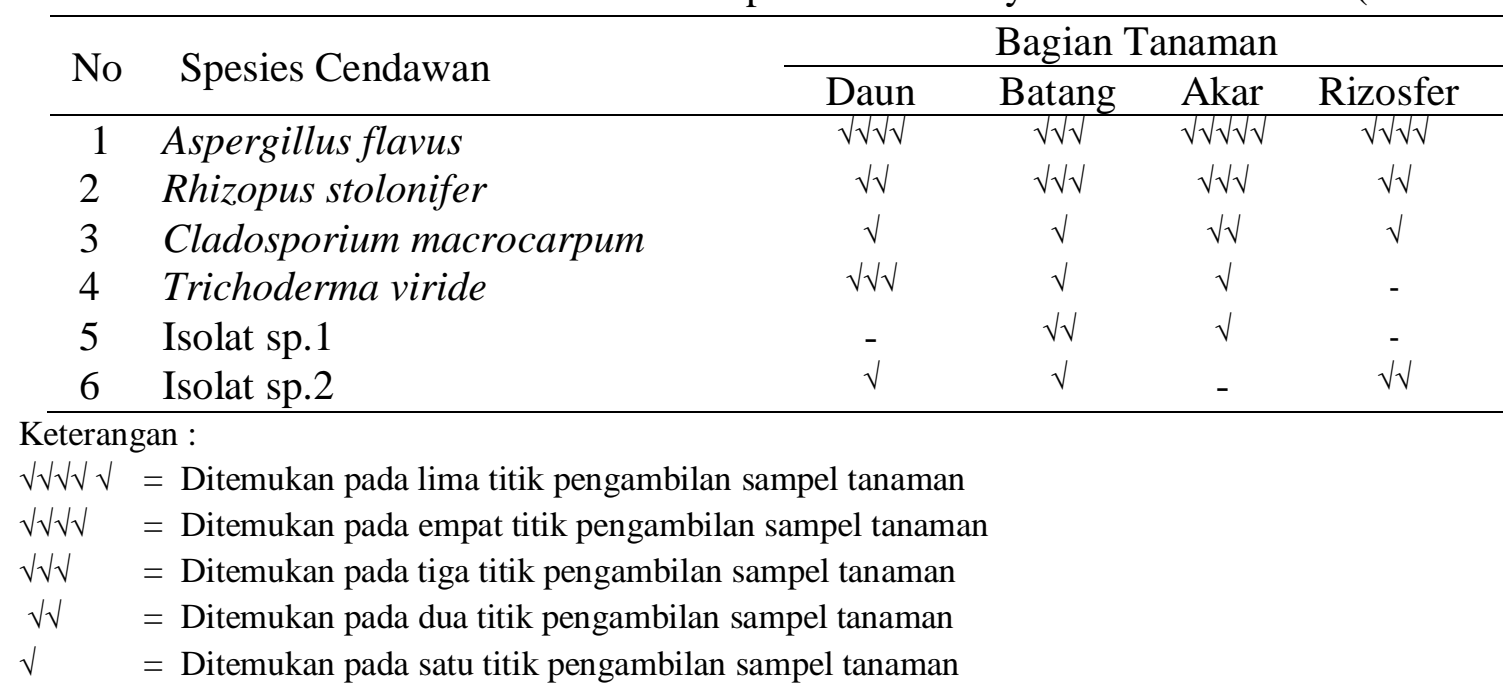
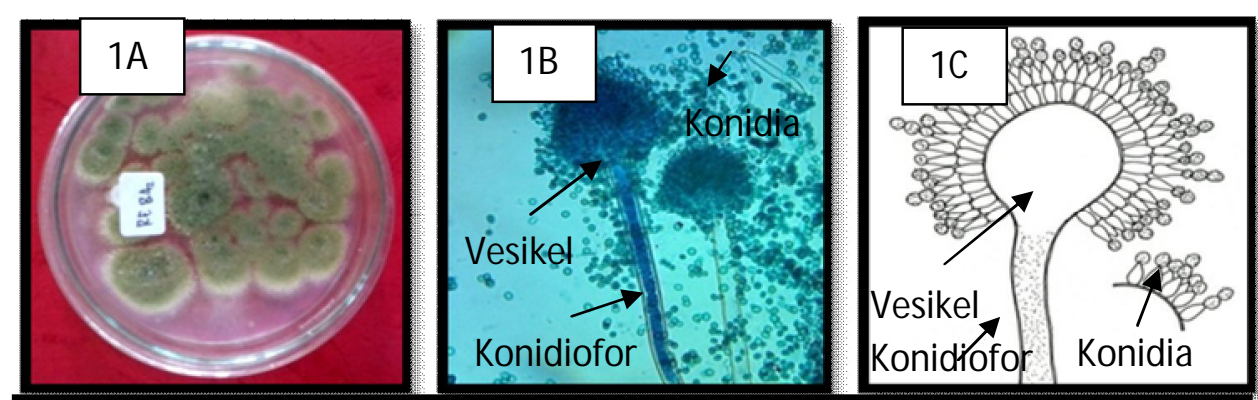

Gambar 1. Aspergillus flavus
A. Koloni Aspergillus flavus
1B. Aspergillus flavus (Perbesaran 400x)

1C. Sketsa Aspergillus flavus

\section{Rhizopus stolonifer}

Koloni tumbuh seperti kapas dalam 3 hari pada media PDA denGan diameter $6 \mathrm{~cm}$. Sebalik koloni putih keabuan, tidak menghasilkan eksudat dan tidak berpigmentasi terhadap media PDA. Secara mikroskopis memiliki rhizoid, kolumela berbentuk bulat, sporangiofor hialin hingga kecoklatan dan sporangoiospora berbentuk bulat dengan berukuran 7,25 $-10 \mu \mathrm{m}$ (Gandjar dkk., 1999).

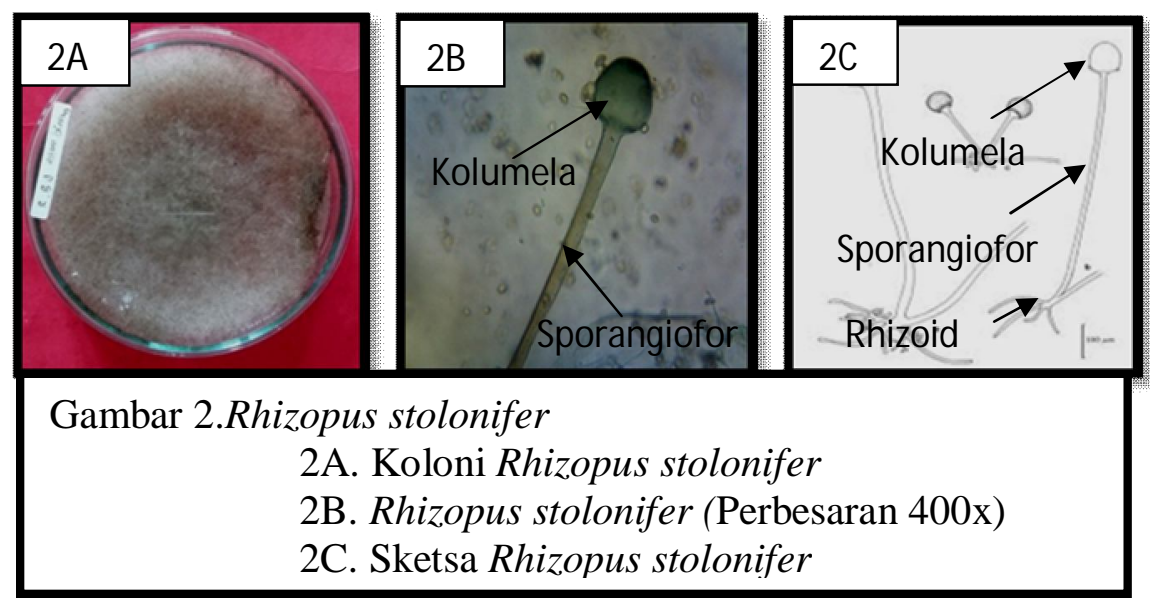




\section{Cladosporium macrocarpum}

Koloni berwarna hijau tua redup hingga hijau tua kehitaman. Konidiofor terbentuk lateral atau terminal pada hifa,panjang mencapai $300 \mu \mathrm{m}$, lebar $3-5 \mu \mathrm{m}$,
Konidia umumnya bersel satu, berbentuk semibulat, berwarna coklat atau coklat kehijauan dan agak kasar (Gandjar dkk., 1999).
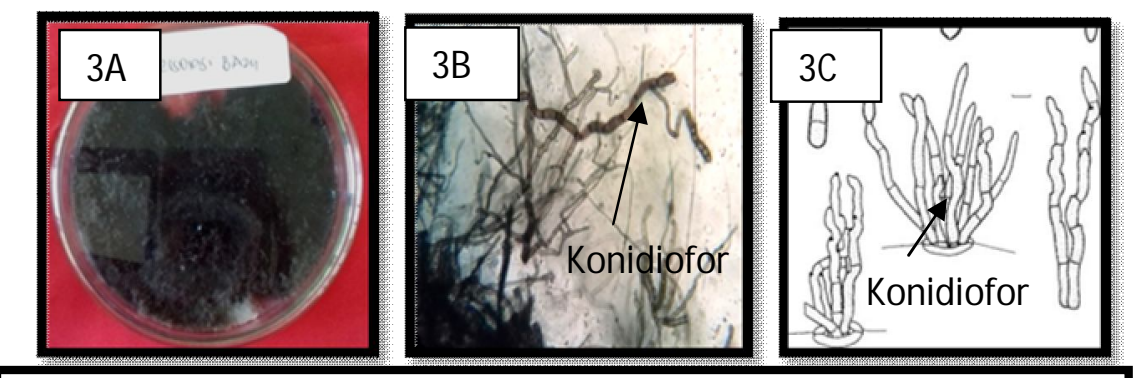

Gambar 3.Cladosporium macrocarpum

3A. KoloniCladosporium macrocarpum

3B.Cladosporium macrocarpum (Perbesaran 400x)

3C. Sketsa Cladosporium macrocarpum

\section{Trichoderma viride}

Koloni dari kapang Trichoderma berwarna putih, kuning, hijau muda, dan hijau tua. Hifa pada jamur ini berbentuk pipih, bersekat, dan bercabang-cabang

membentuk anyaman yang disebut miselium (Gandjar dkk., 1999).

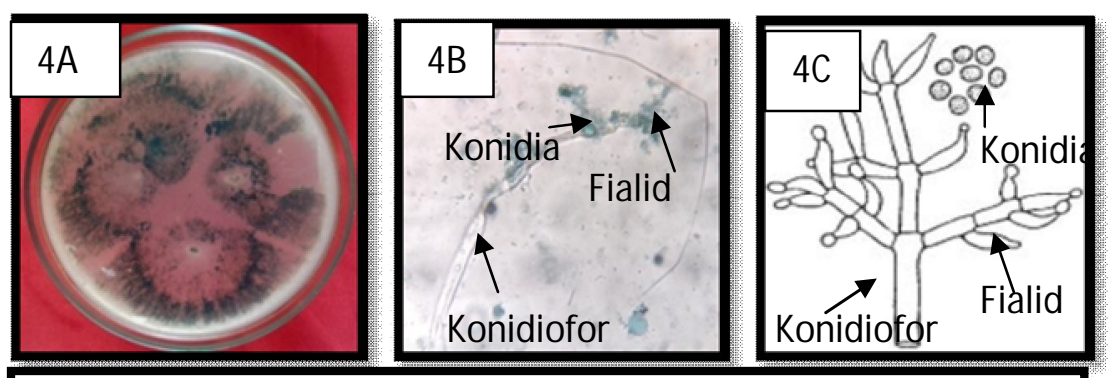

Gambar 4.Trichoderma viride

4A. Koloni Trichoderma viride

4B. Trichoderma viride (Perbesaran 400x)

4C. Sketsa Trichoderma viride

\section{Isolat sp.1 (Tak Teridentifikasi)}

Spesies yang tak teridentifikasi memiliki koloni berwarna merah dengan warna sebalik koloni merah kehitaman, Spesies ini ditemukan pada setiap bagian yan diisolasi.

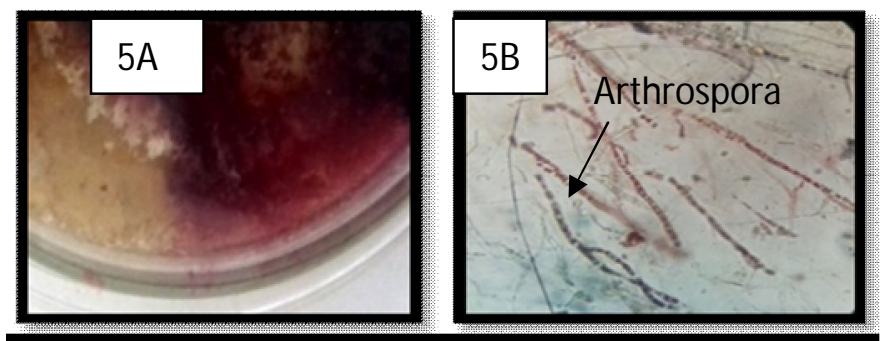

Gambar 5. Isolat sp.1

5A. Koloni Isolat sp. 1

5B. Isolat sp.2 (Perbesaran 400x).

\section{Isolat sp.2 (Tak Teridentifikasi)}

Koloni berwarna putih dengan warna sebalik koloni putih, ditemukan pada setiap bagian yang diisolasi.
Secara mikroskopik, hanya terlihat hifanya saja dan belum membentuk spora.

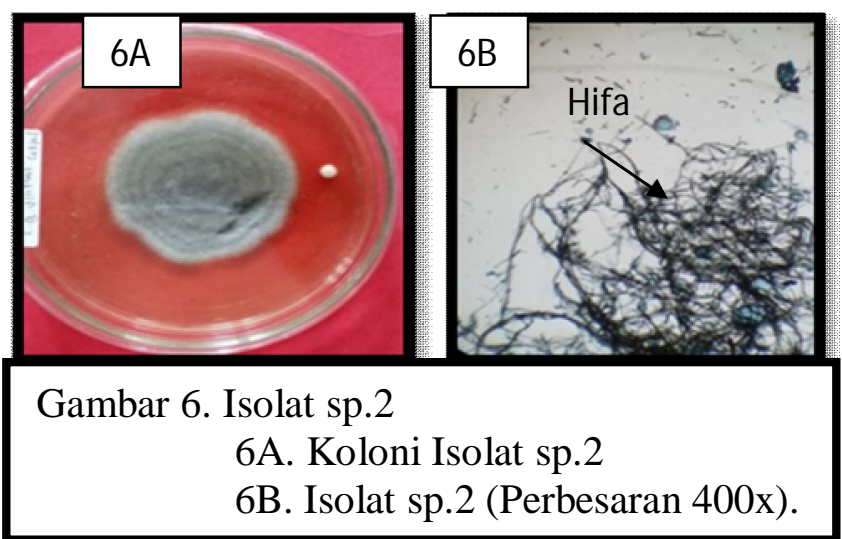




\section{PEMBAHASAN}

Hasil identifikasi cendawan endofit (Tabel 2 dan Tabel 3) yang diperoleh pada kedua lokasi (Desa Tua, Tabanan dan Desa Buahan, Payangan) adalah sebanyak enam, yaitu cendawan teridentifikasi yaitu Aspergillus flavus, Rhizopus stolonifer, Cladosporium macrocarpum, Trichoderma viride, isolatsp.1 dan isolat sp. 2. Menurut Payne (2003), Aspergillus flavus penting sebagai pendaur ulang nutrisi pada sisa-sisa tumbuhan maupun binatang. Konidia Aspergillus flavus tersebar luas melalui udara dan melalui serangga. Cendawan dapat tumbuh optimum pada suhu $33^{\circ} \mathrm{C}-37^{\circ} \mathrm{C}$. Suhu minimum pertumbuhannya adalah $6^{\circ} \mathrm{C}-12^{\circ} \mathrm{C}$. Suhu pertumbuhan maksimumnya adalah berkisar antar $43^{\circ} \mathrm{C}$ $-48^{\circ} \mathrm{C}$ dan memerlukan oksigen yang cukup (Rubini, 2005).

Cendawan Rhizopus stolonifer ditemukan pada semua bagian tanaman kakao yang diisolasi (daun, batang, akar, rizhospher). Namun, cendawan ini paling banyak ditemukan di dataran rendah. Hal tersebut dapat disebabkan karena adanya perbedaan lingkungan dan ketersediaan unsur hara pada tanaman. Berdasarkan hasil isolasi dan identifikasi, Trichoderma viride adalah salah satu cendawan tanah yang tersebar luas (kosmopolitan), yang hampir dapat ditemui di lahanlahan pertanian dan perkebunan. Trichoderma viride bersifat saprofit pada tanah, kayu dan beberapa jenis bersifat parasit pada jamur lain (Prayogo, 2005).

Cendawan lain yang teridentifikasi adalah Cladosporium macrocarpum. Pada dataran rendah dan dataran tinggi cendawan ini teridentifikasi pada daun, batang dan akar tanaman. Pengamatan yang dilakukan pada lima sampel, cendawan ini hanya ditemukan pada tiga sampel daun, satu sampel batang dan satu sampel akar. Menurut Ogoshi (1985), cendawan ini umumnya patogen pada tanaman, pengendali hayati untuk cendawan dan hama, endofit maupun saproba yang hidup di banyak tempat seperti pada bekas tanaman, tanah, air, dan udara.

Isolat sp.1 ditemukan pada batang dan akar didataran rendah sebanyak satu isolat dan pada daun serta akar didataran tinggi sebanyak dua isolat. Isolat 2 ditemukan di semua organ tanaman kakao yang terdapat pada kedua lokasi. Perbedaan lokasi dan lingkungan mempengaruhiperbedaan jumlah cendawan, dimana pada lokasi dataran tinggi, tingkat kelembaban dan curah hujan cukup tinggi namun dengan tingginya curah hujan dapat menyebabkan beberapa bahan-bahan organik yang terdapat rizosfer tanaman banyak terbawa aliran air hujan sehingga tanaman tidak dapat menyerap banyak nutrisi tersebut.

Menurut Aziz dkk., (2014), tanah dihuni oleh bermacam-macam mikroorganisme. Semakin subur tanah, semakin banyak mikroorganisme yang terkandung didalamnya. Berdasarkan hasil wawancara secara langsung dengan pemilik kebun kakao di desa Tua (Tabanan), mereka menggunakan pupuk hayati bahkan sisa ternak tanpa adanya pupuk kimia didalamnya. Hal ini berpengaruh juga terhadap keberadaan cendawan endofit pada kakao tersebut. Menurut Prayogo (2005), kualitas dan kuantitas bahan organik yang ada dalam tanah mempunyai pengaruh langsung terhadap jumlah keberadaan cendawan dalam tanah, karena jamur dalam tanah nutrisinya heterotrofik. Demikian juga Sutedjo (1991), menyatakan bahwa cendawan tanah tergantung pada ketersediaan bahan organik dan cendawan (jamur) sangat sensitif terhadap tanah kering, sehingga pada tanah yang kering kandungan jamurnya rendah. Perbedaaan kondisi tanah dan iklim dapat menghasilkan perbedaan dalam habitat yang penting bagi setiap organisme yang ada didalamnya, karena suatu organisme akan ada pada suatu area yang faktor - faktor ekologinya tersedia dan sesuai bagi kehidupannya (Sunyartini, 2003).

\section{SIMPULAN}

Cendawan (endofit) terdapat pada tanaman kakao (Theobroma cacao L.) yang diperoleh pada dua kawasan yang berbeda (Desa Tua, Tabanan dan Desa Buahan, Payangan). Tidak ditemukan perbedaan jenis cendawan (endofit) yang diperoleh pada dua kawasan yang berbeda. Perbedaan hanya terdapat pada sampel ditemukan atau tidak ditemukannya pada daun, batang, akar atau rizosfer tanaman. Cendawan yang teridentifikasi yaitu Aspergillus flavus, Rhizopus stolonifer, Cladosporium macrocarpum, Trichoderma viride, isolat sp. 1 dan isolat sp. 2 .

\section{KEPUSTAKAAN}

Aziz AI, Rosmana A, Dewi VS. 2014. Pengendalian Penyakit Hawar Daun Phytophthora pada Bibit Kakao dengan Trichoderma asperellum. J Fitopatol Indonesia. 9:15-20.

Badrun, M. 1991. Program Pengembangan Kakao di Indonesia. Prosiding Komperensi Nasional Kakao III. Medan. Buku 2:1-9

CABI [Commonweal Agricultural Bureaux International]. 2004. Crop Protection Compendium.

Dinas Perkebunan. 2010. Peluang atau Prospek Pengembangan Perkebunan. Provinsi Jawa Barat: Disbun.

Dinas Perkebunan Kehutanan Tanaman Pangan dan Hortikultura. 2011. Laporan Hasil Pelaksanaan Kegiatan SL-PHT Kakao. Pringsewu: Dinas perkebunan Kabupaten Pringsewu.

Firdausil, A.B., Nasriati, dan A. Yani. 2008. Teknologi Budidaya Kakao. Balai Besar Pengkajian dan Pengembangan Teknologi Pertanian. Badan Penelitian dan Pengembangan Pertanian.

Fitrianti, D. 2014. Isolasi dan Identifikasi Cendawan Endofit Pada Bibit Kakao.[Skripsi]. Program Studi Agroteknologi Jurusan Hama dan Penyakit Tumbuhan. Fakultas Pertanian.

Irmawan, D. E. 2007. Kelimpahan Keragaman Cendawan Endofit pada Beberapa Varietas Padi di Kuningan, Tasikmalaya dan Subang, Jawa Barat. [Skripsi].Fakultas Pertanian, IPB. Bogor.

Istikorini, Y. 2005. Eksplorasi Cendawan Endofit dari Tanaman Cabai (Capsicum annum L.) dan Teki 
(Cyperus rotundus). Jurnal Penelitian

Universitas Jambi Seri Sains.13(1):33-38.

Mulato, S dan S. Widyotomo. 2003. Teknik Budidaya dan Pengolahan Hasil Tanaman Kakao. Pusat Penelitian Kopi dan Kakao Indonesia. Jember.

Nurhayati, S., Sari, F.B.P, dan Taukhid. 2009. Identifikasi Dan Uji Postulat Koch Cendawan Penyebab Penyakit Pada Ikan Gurame. Jurnal AkuakulturIndonesia. 8(2):21-29.

Proborini, M. W. 2002. Eksplorasi Jenis-Jenis Endomikoriza Indigenus pada Lahan Kering di Bali Dan Pemanfaatannya pada Pembibitan Mente (Anacardium ocidentale). Laporan Hibah Doktor. DANA DIPA Universitas Udayana. Bali

Pelczar, J.M., Chan E.C.S. 2006. Dasar-dasar Mikrobiologi II. UI-PRESS. Jakarta.

Pelczar. M.J. 1988. Dasar - Dasar Mikrobiologi 2. Jakarta : Universitas Indonesia (UI Press).

Prayogo. 2005. Keragaman Cendawan Endofit pada Buah Kakao dan Potensinya Dalam Mengendalikan Busuk Buah Phytophthora. [Disertasi]. Bogor (ID): Sekolah Pascasarjana, Institut Pertanian Bogor.

Purwantisari, S., R.S. Ferniah, dan B. Rahrjo.2008. Pengendalian Hayati Penyakit Lodoh (Busuk Umbi Kentang) dengm Agsrr Hayati JamurJamur Antagonis Isolat Lokal. Jurnal HPT.(I)0: I 3- 19.

Sunyartini, M. 2003. Pengaruh Mikroba Antagonis Terhadap Pertumbuhan Aspergillus Flavus dan Produksi Aflatoksin serta Kandungan Nutrisi Kacang Tanah. Pascasarjana Bioteknologi Pertanian Universitas udayana. 52 hal.

Sutedjo, M.M. 1991. Mikrobiologi Tanah. Penerbit Rineka Cipta, Jakarta.

Schadt CW, Mullen RB, Schmidt SK. 2001. Isolation And Phylogenetic Identification Of A DarkSeptate Fungus Associated With The Alpine Plant Ranunculus adoneus. New Phytol. 150:747-755.

Ogoshi N, Ntougias S, Zervakis GI, Ehaliotis C Haralampidis K, Papadopoulou KK. 2007. Role Of Ethylene In The Protection Of Tomato Plants Against Soil- 